\title{
The Effect of High Frequency Sensorineural Hearing Loss on Auditory Temporal Resolution: Gaps-In-Noise Test Performance in Older and Young Adults with Normal Hearing
}

\author{
Yong Kyung Kang, Eun Sub Lee, Sang Won Yoon, Hyun Joon Shim, and Yong-Hwi An \\ Department of Otorhinolaryngology, Eulji Medical Center, Eulji University School of Medicine, Seoul, Korea
}

\begin{abstract}
정상 청력인 노인과 젊은 성인에서 고음역 감각신경성 난청이 청각의 시간적 해상도에 미치는 영향: Gaps-In-Noise 검사 수행력
\end{abstract}

강용경 · 이은섭 · 윤상원 · 심현준 · 안용휘

을지대학교 의과대학 을지병원 이비인후과학교실

Received June 18, 2015

Revised August 18, 2015

Accepted August 29, 2015

Address for correspondence

Yong-Hwi An, MD

Department of Otorhinolaryngology,

Eulji Medical Center,

Eulji University School of Medicine,

68 Hangeulbiseok-ro, Nowon-gu,

Seoul 01830, Korea

Tel $+82-2-970-8276$

Fax $+82-2-970-8275$

E-mailan0072@hanmail.net
Background and Objectives Auditory temporal resolution, which refers to the time-related aspects of acoustic processing, can be evaluated by the Gaps-In-Noise (GIN) test. We investigated whether the presence of high frequency sensorineural hearing loss (HF-SNHL) affects the temporal resolution of GIN performance in older adults with normal hearing.

Subjects and Method Hearing tests including the GIN test were performed in 87 subjects with normal pure tone average. The GIN threshold and percentage of correct answers were compared among 4 groups of participants; older adults with normal hearing $(n=18)$, older adults with HF-SNHL $(n=24)$, young adults with normal hearing $(n=24)$ and young adults with HF-SNHL $(\mathrm{n}=21)$.

Results There was no significant difference in the mean GIN thresholds between the HFSNHL group $(5.8 \pm 0.8 \mathrm{msec})$ and the normal hearing group $(6.0 \pm 0.8 \mathrm{msec})$ in older adults, whereas the mean GIN thresholds of HF-SNHL group was higher than that of the normal group in young adults $(4.6 \pm 0.3 \mathrm{msec}$ vs. $4.2 \pm 0.5 \mathrm{msec}, p<0.05)$. The mean percentage of correct answers of HF-SNHL group $(62.5 \pm 5.5 \%)$ was not significantly different from that of the normal hearing group $(60.6 \pm 3.9 \%)$ in the old, unlike in the young $(71.3 \pm 4.0 \%$ with HF-SNHL vs. $76.9 \pm 4.3 \%$ with normal hearing, $p<0.05$ ). Age only showed a significant correlation with the GIN performance. Neither the GIN threshold nor the GIN perception level had any relation with the presence of HF-SNHL in older adults.

Conclusion We found no evidence that supported the influence of HF-SNHL on auditory temporal resolution in older adults. These results imply that HF-SNHL may be of little importance in gap detection after age-related changes in central auditory system.

Korean J Otorhinolaryngol-Head Neck Surg 2015;58(12):841-7

Key Words Age - Gaps-In-Noise test · High-frequency hearing loss · Temporal resolution.

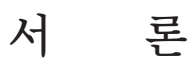

좁은 의미로 청각의 시간적 해상도(auditory temporal reso- lution)란 귀를 통해 두 개의 다른 소리 신호를 구분할 수 있는 가장 짧은 시간 간격을 의미한다.,2) 넓게는 청각에 대한 시간 적 처리(auditory temporal processing)의 한 범주로서, 시간적 
해상도는 우리 몸의 청각계가 시간에 따른 소리 자극의 전체 적인 외양(envelope) 변화와 소리 압력의 빠른 변화(fine structure)를 인지하는 능력으로 정의할 수 있다. ${ }^{2-6)}$ 시간적 해 상도가 정확한 청각 인지에 중요한 요소임에도 불구하고 이를 평가하는 임상적인 검사는 시간 및 비용적인 측면에서 매우 제한적이다. 전통적으로 다양한 환자군에서 시간적 해상도의 이상 소견을 확인하는 데 시간적 변조 변환 함수(temporal modulation transfer function)와 간격 탐지 역치(gap detection threshold)가 이용되어 왔다. ${ }^{3-5)} \mathrm{Gaps}-\mathrm{In}-\mathrm{Noise}(\mathrm{GIN})$ 검사는 이전의 간격 역치 측정의 시간과 인력이 소모되는 단점을 극 복하기 위해 2005년에 개발되었고, 이후 다수의 연구자들은 $\mathrm{GIN}$ 검사가 정상 청력 성인, ${ }^{6,7)}$ 정상 소아, ${ }^{8)}$ 중추 청각 질환을 가진 환자, () 이명이나 난청이 동반된 환자들 ${ }^{19)}$ 에서 일관적으 로 신뢰할 만한 결과를 나타낸다고 보고하고 있다. GIN 검사 의 수행력은 시간적 해상도를 평가하는 데 유용한 심리음향 요소(psychoacoustic parameter)이며, 시간적 처리의 다른 범 주인 청각의 시간적 통합(temporal integration) 능력을 확인 하는 것은 가능하지 않다.

간격 탐지 능력은 일반적으로 감각신경성 난청의 심한 정도 에 따라 감소하는 경향이 있지만, 청력검사 결과 자체만으로 는 예측되기 어렵다고 알려져 있다. 비슷한 정도와 양상의 난 청을 보이는 환자들이 시간적 간격을 감지하는 검사에서 다 양한 능력을 보였고, ${ }^{10)}$ 동일한 순음청력도를 보이는 환자군에 서도 언어 인지와 시간적 해상도 간에 상관 관계가 뚜렷하지 않았다. ${ }^{11)}$ 이러한 불일치는 기관의 검사실 별로 간격 탐지 검 사에 이용되는 자극과 절차상 약간의 차이가 있기 때문이기 도 하고, 순음청력이나 언어청력 이외의 다른 요인들이 시간 적 해상도에 영향을 미치기 때문이기도 하다. 그중의 하나가 나이 증가에 따라 간격 탐지 수행력이 감소하는 것이다. 청력 이 같을 경우 젊은 성인에서보다 고령에서 간격 탐지 역치가 거 의 항상 더 높게 나오는 것으로 보아,1,12) 나이는 청각의 시간적 해상도에 관여하는 가장 확실한 요인 중 하나라고 볼 수 있다.

순음청력 역치의 평균이 정상이더라도 고음역의 감각신경성 난청이 존재할 경우 소음 환경에서의 언어 인식이 떨어질 뿐만 아니라 시간적 해상도도 감소될 수 있다. ${ }^{413)}$ 하지만, 기존의 보 고들은 젊은 성인이나 난청이 있는 노인들을 대상으로 조사되 어, 순음청력 평균이 정상인 노인에서 고음역 난청 자체가 시 간적 해상도에 미치는 효과에 대해서는 알려진 바가 거의 없 다. 젊은 성인에서와 마찬가지로 노인에서도 고음역 난청이 청 각의 시간적 해상도에 영향을 준다는 가설을 증명하기 위하여 본 연구에서는 GIN 검사를 통해 순음청력 평균이 정상인 노인 과 젊은 성인들을 대상으로 하여 고음역 감각신경성 난청의 유 무가 시간적 해상도에 영향을 미치는지 알아보고자 하였다.

\section{대상 및 방법}

\section{대 상}

2011년에서 2014년까지 귀 이외의 다른 질환으로 본 병원 이비인후과를 방문한 정상 청력을 가진 만 65세 이상 만 70세 이하의 노인 지원자들 중, 진찰상 양측 고막이 정상 소견이며 순음청력검사상 $0.5,1,2,4 \mathrm{kHz}$ 의 6 분법 순음역치 평균이 25 $\mathrm{dB} \mathrm{HL}$ 이하의 정상 범위를 보이는 42 명(평균 나이 $67.6 \pm 1.8$ 세, 범위 65 70세; 남자 20명, 여자 22명)의 의무기록을 전향 적으로 분석하였다. 동일한 기간에 귀 이외의 다른 질환으로 본 병원 이비인후과를 방문한 순음청력 평균이 정상인 만 20 세 이상 만 30세 미만의 젊은 성인 지원자들 중 45 명(평균 나 이 25.4 \pm 2.8세, 범위 20 29세; 남자 21명, 여자 24명)의 검사 결과를 대조군으로 이용하였다. 이전에 난청이나 어지럼증 병 력이 있는 자, 나이가 만 70세 초과인 자, 중이염 등 이과적 질 환이 있는 자, 급성 청각 외상 및 이독성 약물 사용의 과거력 이 있는 자, 왼손잡이 또는 양손잡이는 제외하였다.

본 연구에서 고음역의 감각신경성 난청은 순음청력검사상 $4,8 \mathrm{kHz}$ 의 기도-골도 청력 역치의 차이가 각각 $5 \mathrm{~dB} \mathrm{HL}$ 이 하이고, $4,8 \mathrm{kHz}$ 의 청력 역치가 평균 $25 \mathrm{~dB} \mathrm{HL}$ 초과이면서 동시에 $4,8 \mathrm{kHz}$ 의 청력 역치 중 하나 이상이 $40 \mathrm{~dB}$ 이상인 경우로 정의하였다. $4 \mathrm{kHz}$ 와 $8 \mathrm{kHz}$ 의 역치 차이가 $20 \mathrm{~dB}$ 이 상 차이가 있는 경우 $6 \mathrm{kHz}$ 에서도 역치 검사를 시행하여 난 청의 유무를 확인하였고, 이 경우 $6 \mathrm{kHz}$ 에서도 $30 \mathrm{~dB}$ 이상의 청력 감소가 확인된 대상자만을 연구에 포함시켰다. 양측 귀 의 순음청력도상 $0.25,0.5,1,2,3,4,8 \mathrm{kHz}$ 까지 모든 주파수 에서 $10 \mathrm{~dB} \mathrm{HL}$ 이내의 대칭형 청력을 보인 경우에만 연구대 상에 포함하였고, 순음청력검사에서 두 개 이상의 연속된 주 파수에서의 $10 \mathrm{~dB} \mathrm{HL}$ 초과의 차이가 있거나 한 개의 주파수 이상에서 $20 \mathrm{~dB} \mathrm{HL}$ 초과의 차이가 있는 비대칭 청력이 있는 자는 제외하였다. 나이와 감각신경성 난청의 유무에 따른 GIN 검사의 선행연구)를 참조하여 예상되는 GIN 역치(threshold) 를 $1.5 \mathrm{msec}$, 표준편차를 2.5 로 산출한 목표시험자 수는 정상 청력 노인군과 고음역 난청 노인군 각각 21명이었다.

총 87 명의 대상자들은 나이와 고음역 감각신경성 난청의 유 무에 따라 다음의 4 개 군으로 분류되었다; 정상 청력 노인군 18 명, 고음역 난청 노인군 24명, 정상 청력 젊은 성인군 24 명, 고음역 난청 젊은 성인군 21 명. 모든 대상자들은 검사에 자원 하였고, 검사 참여 당일에 이비인후과 외래에서 문진, 이학적 검사 후 순음청력검사, 어음청력검사, GIN 검사를 시행하였 다. 청력검사와 GIN 검사는 양측 귀에서 시행되었고, 좌우 측 간에 유의한 차이를 보이지 않아 우측 귀의 결과를 이용하여 4 개의 군 간에 비교 분석하였다. 


\section{$\mathrm{GIN}$ 검사}

시간적 해상도를 평가하기 위해 GIN 검사를 Musiek 등에 에 의해 처음 제작된 대로 수행하였으며, 모든 대상자들은 방음 실에서 앉은 채로 좌우 측 각각을 검사받았다. GIN 자극이 포 함된 $\mathrm{CD}$ 가 청력검사 기계와 연결된 $\mathrm{CD}$ 플레이어에서 재생되 었다. 좌우 측 각각의 어음 인지 역치(speech reception threshold)를 기준으로 $50 \mathrm{~dB}$ sensation level의 GIN 자극을 일측 귀

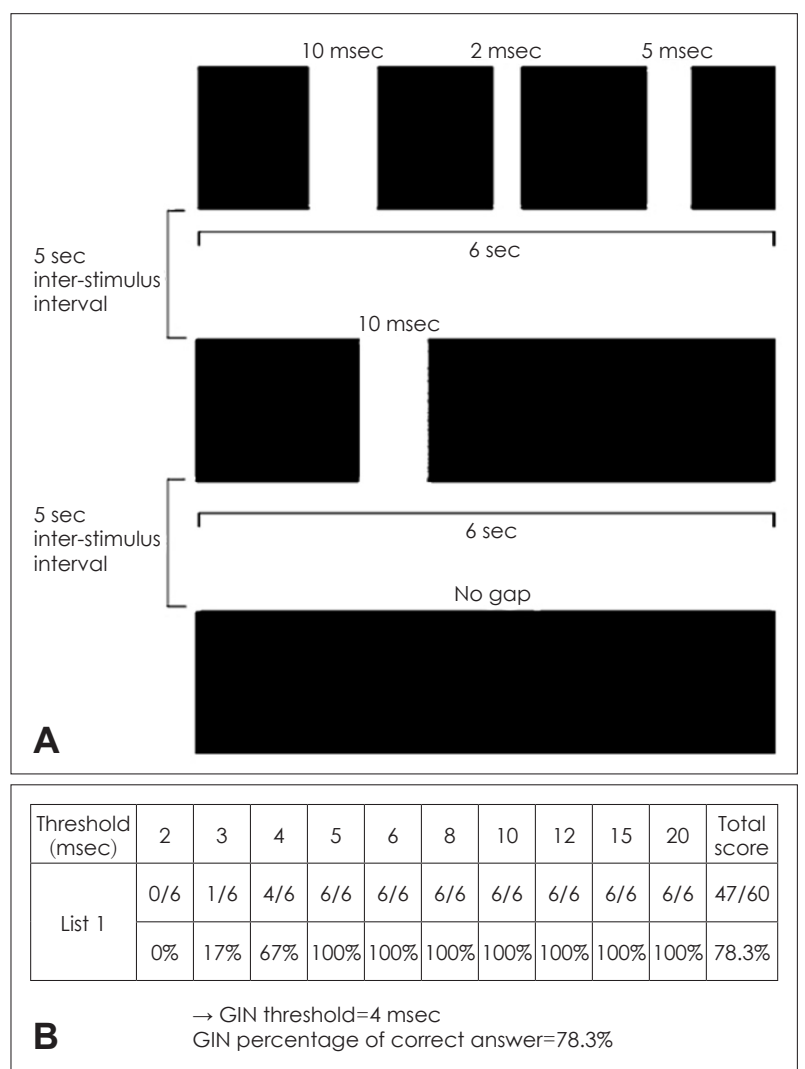

Fig. 1. Gaps-In-Noise (GIN) test. Samples of three white noise segments demonstrating the duration of the stimuli, inter-stimulus intervals, and varying 0 to 3 silent gaps durations (A). An example of a completed score sheet showing the numbers and percentages of correctly identified gaps at all gap durations, the GIN threshold, and the GIN percentage of correct answer (B).
에 주었다. GIN 검사는 각 잡음 분절마다 무음 간격(silent gap) 구간을 포함하는 6초의 백색 잡음(white noise) 분절을 기본으로 구성되어 있다. 각 6초의 잡음 분절 중에 무음 간격 구간의 개수는 $0,1,2$, 또는 3 개이다. 연속적인 잡음 분절 사 이의 자극 간의 간격은 5 초이고, 간격의 지속 기간은 $2,3,4$, $5,6,8,10,12,15$, 또는 $20 \mathrm{msec}$ 이다(Fig. 1A). GIN 검사에는 4개의 목록(list)이 있고, 각각의 목록에는 2 $20 \mathrm{msec}$ 열 가지 의 모든 무음 간격에 대해 6개씩의 잡음 분절이 존재하여 목 록당 총 60 개의 무음 간격이 포함된다. 간격의 지속 기간과 잡 음 분절 내에서 간격의 위치는 각각의 발생률에 대해 의사-무 작위 추출화(pseudorandomization)되어 있다.

GIN 검사의 결과는 GIN 역치(threshold)와 GIN 정답 백분 율(percentage of correct answers), 두 가지로 확인되었다. GIN 역치는 무음 간격에 대해 최소 6번 중 4번(67\%)을 올바르게 인지하는 가장 짧은 간격의 지속 기간으로 정의하였다. 각 목 록마다 총 60개의 간격이 있기에 GIN 정답 백분율은 (올바르 게 인지된 gap의 총 수/리스트의 모든 gap의 수, 즉 60)× $100(\%)$ 로 계산되게 되었다. 예를 들어, Fig. 1B에서처럼 5 $\mathrm{msec}$ 이상의 무음 간격에 대해서는 모두 무음의 존재를 인지 하면서 6 번의 $4 \mathrm{msec}$ 간격 중 4번을 맞추면 $\mathrm{GIN}$ 역치는 4 $\mathrm{msec}$ 이고, 총 60 개의 간격 중 47 개를 올바르게 인지한 경우 $\mathrm{GIN}$ 정답 백분율은 $78.3 \%$ 로 계산된다.

모든 통계적 처리는 SPSS 12.0판(SPSS Inc., Chicago, IL, USA)을 이용하여 실시하였다. 두 군 간(between-group comparisons)의 연령, 성별, 순음청력평균, 어음청취역치, 어음명료 도, GIN 역치, GIN 정답 백분율을 비교하기 위해 MannWhitney U-test를 이용하였고, 청력검사 결과들과 GIN 수행 력의 관련성은 다중 회귀분석을 통해 통계적인 유의성을 확인 하였다. 각각의 변수들은 평균ㅍㅍㅍ준편차의 형식으로 기술되었 고, 유의수준은 0.05 미만을 의미 있는 것으로 해석하였다. 이 연구는 본 병원의 기관윤리심의위원회의 심의를 통과하였다.

Table 1. Patients characteristics

\begin{tabular}{lcccc}
\hline & $\begin{array}{c}\text { Older adults with } \\
\text { normal hearing }(\mathrm{n}=18)\end{array}$ & $\begin{array}{c}\text { Older adults } \\
\text { with HF-SNHL }(\mathrm{n}=24)\end{array}$ & $\begin{array}{c}\text { Young adults } \\
\text { with normal hearing }(\mathrm{n}=24)\end{array}$ & $\begin{array}{c}\text { Young adults } \\
\text { with HF-SNHL }(\mathrm{n}=21)\end{array}$ \\
\hline Mean age (years) & $67.1 \pm 1.7$ & $68.0 \pm 1.8$ & $25.4 \pm 3.0$ & $25.3 \pm 2.6$ \\
Range of age (years) & $65-70$ & $66-70$ & $20-29$ & $21-29$ \\
$\begin{array}{l}\text { Sex }(\mathrm{M}: \mathrm{F}) \\
\begin{array}{l}\text { Mean pure tone } \\
\text { average }(\mathrm{dB} \mathrm{HL})\end{array}\end{array}$ & $11: 7$ & $9: 15$ & $13: 11$ & $8: 13$ \\
$\begin{array}{l}\text { Mean speech reception } \\
\text { threshold (dB HL) }\end{array}$ & $11.1 \pm 4.7$ & $14.5 \pm 6.5$ & $6.5 \pm 3.6$ & $7.3 \pm 4.3$ \\
$\begin{array}{l}\text { Mean speech } \\
\text { discrimination score }(\%)\end{array}$ & $96.0 \pm 4.9$ & $12.7 \pm 7.1$ & $6.9 \pm 3.6$ & $8.6 \pm 2.8$ \\
\hline
\end{tabular}

HF-SNHL: high frequency sensorineural hearing loss 


\section{결 과}

정상 청력 노인군 18 명과 고음역 감각신경성 난청 노인군 24 명 간에 연령, 성비, 순음청력평균, 어음청취역치, 어음명료도 는 유의한 차이를 보이지 않았다(Table 1). 정상 청력인 젊은
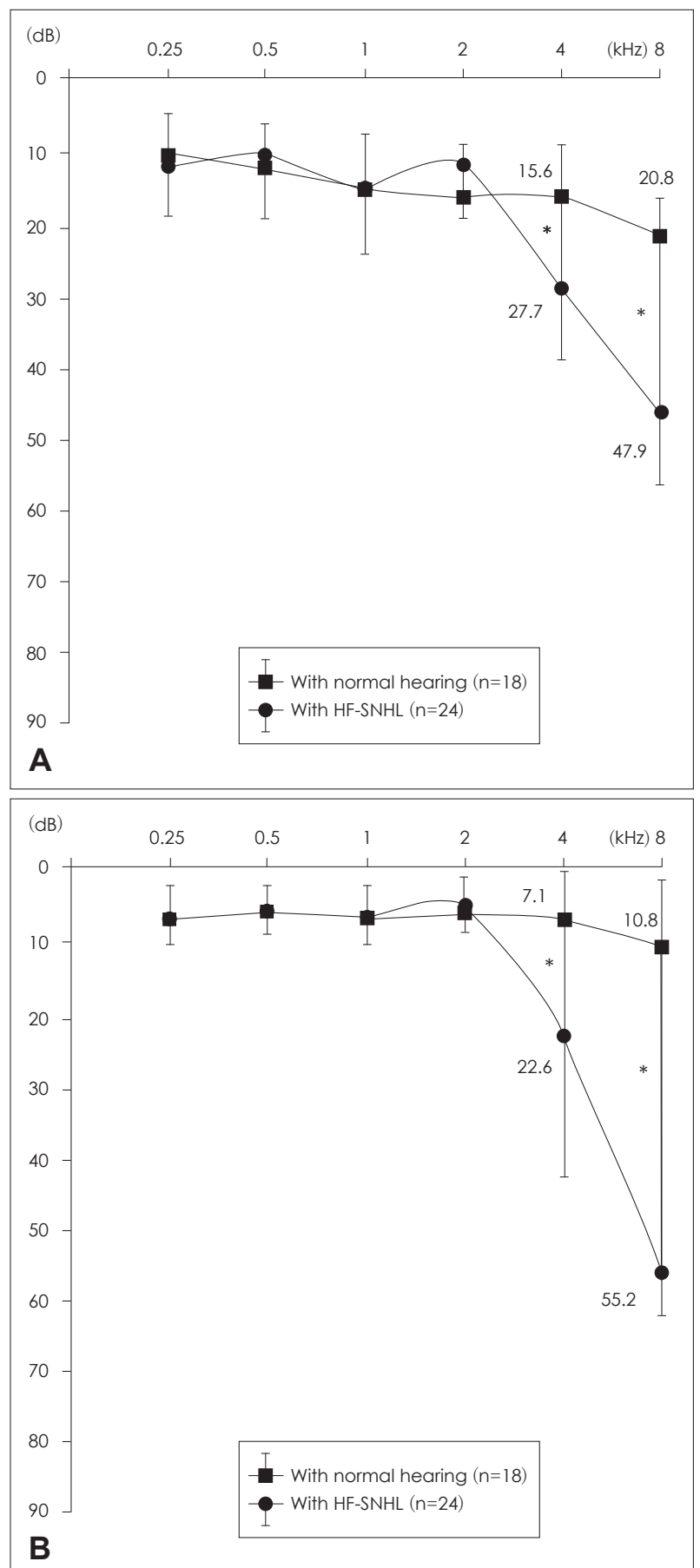

Fig. 2. Comparison of mean pure tone thresholds between subjects with normal hearing and high frequency sensorineural hearing loss (HF-SNHL). Note that differences of thresholds at high frequency in older adults $(A)$ and young adults $(B)$ are statistically significant $\left({ }^{*} p<0.001\right)$.
성인군 24명과 고음역 난청의 젊은 성인군 21 명 간에도 연령, 성비, 순음청력평균, 어음청취역치, 어음명료도는 유의한 차이 를 보이지 않았다. 정상 청력인 노인군에 비해 정상 청력인 젊 은 성인군에서 순음청력평균과 어음청취역치는 낮게, 어음명 료도는 높게 나타났고 $(p<0.001)$, 고음역의 감각신경성 난청이 있는 대상자들 중에서도 노인군에서보다 젊은 성인군에서 순 음청력평균과 어음청취역치는 낮게, 어음명료도는 높게 나타났 다 $(p<0.001)$. 노인 대상자에서 $4 \mathrm{kHz}$ 이상의 고주파 청력 역치 의 평균은 정상 청력군 $18.2 \pm 4.6 \mathrm{~dB}$, 고음역 난청군 $37.8 \pm 10.9$ $\mathrm{dB}$ 로 두 군 간에 유의한 차이를 보였고(Fig. $2 \mathrm{~A}$ ), 젊은 성인군 에서 $4 \mathrm{kHz}$ 이상의 고주파 청력 역치의 평균은 정상 청력군 $9.0 \pm 7.2 \mathrm{~dB}$, 고음역 난청군 $38.9 \pm 17.7 \mathrm{~dB}$ 로 두 군 간에 유의 한 차이를 보였다 $(p<0.001)$ (Fig. $2 \mathrm{~B}$ ). 고음역 난청이 있는 노 인군과 고음역 난청이 있는 젊은 성인군 간에 $4 \mathrm{kHz}$ 이상의 고주파 청력 역치의 평균은 유의한 차이를 보이지 않았다. 모 든 대상자들 중에서 $4 \mathrm{kHz}$ 의 청력 감소가 특징적인 C-5 dip 을 보이는 경우는 없었다.

$\mathrm{GIN}$ 역치의 평균값은 정상 청력 노인군에서 $6.0 \pm 0.8 \mathrm{msec}$, 고음역 난청 노인군에서 $5.8 \pm 0.8 \mathrm{msec}$ 으로 두 군 간에 유의 한 차이는 없었고, 젊은 성인에서는 정상 청력군보다 고음역 난청군에서 유의하게 더 높게 측정되었다 $(4.2 \pm 0.5 \mathrm{msec}$ vs. $4.6 \pm$ $0.3 \mathrm{msec}, p<0.05$ )(Fig. 3). GIN 정답 백분율의 평균값은 정상 청력 노인군에서 $60.6 \pm 3.9 \%$, 고음역 난청 노인군에서 $62.5 \pm$ $5.5 \%$ 로 두 군 간에 유의한 차이는 없었고, 젊은 성인에서는 정상 청력군보다 고음역 난청군에서 유의하게 더 낮게 측정되 었다(76.9 $\pm 4.3 \%$ vs. $71.3 \pm 4.0 \%, p<0.05$ )(Fig. 4). 각각의 간격 지속기간에 대한 GIN 정답 백분율의 심리측정 함수(psychometric function) 분석은 Fig. 5 와 같다. 노인에서는 $2 \mathrm{msec}, 3$ $\mathrm{msec}, 4 \mathrm{msec}$ 의 간격에 대한 정답률은 모두 $0 \%$ 였고, $5 \mathrm{msec}$ 에

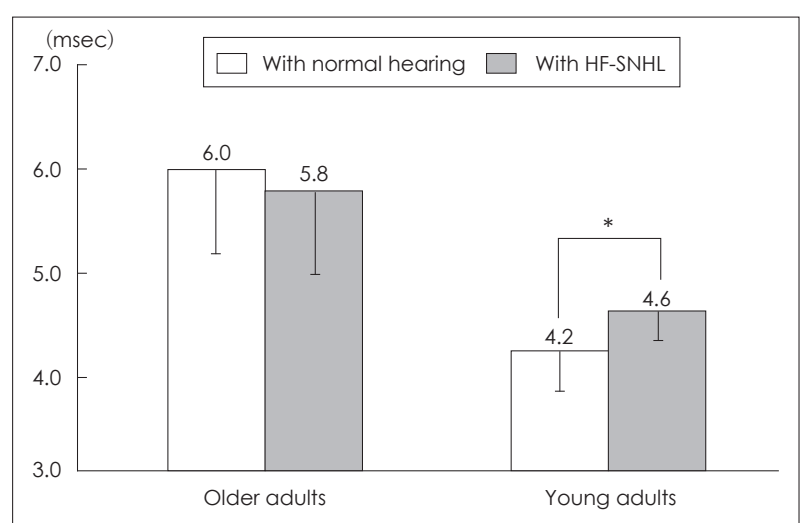

Fig. 3. Comparison of the Gaps-In-Noise (GIN) threshold between subjects with normal hearing and high frequency sensorineural hearing loss (HF-SNHL). There was no significant difference of the mean GIN thresholds in older adults, whereas that of young adults with HF-SNHL was significantly higher than that of young adults with normal hearing $\left({ }^{*} p<0.05\right)$. 


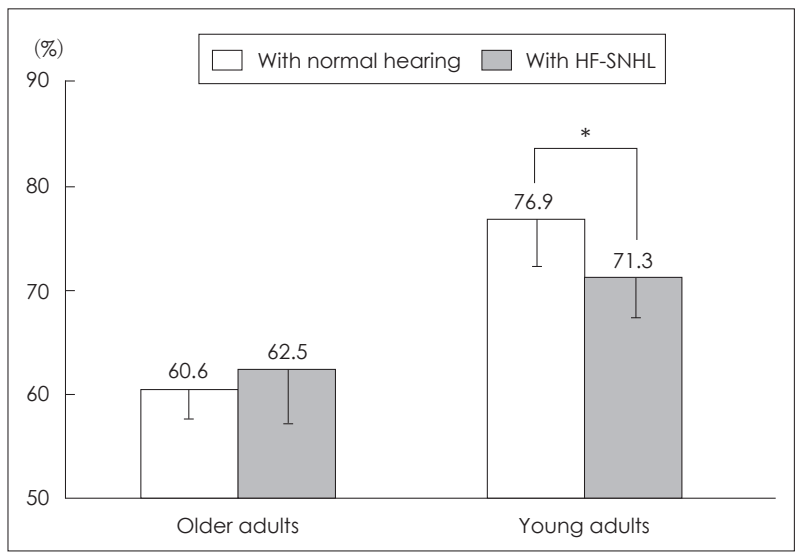

Fig. 4. Comparison of the Gaps-In-Noise (GIN) percentage of correct identifications between subjects with normal hearing and high frequency sensorineural hearing loss (HF-SNHL). There was no significant difference of the mean GIN percentage of correct answers in older adults, whereas that of young adults with HFSNHL was significantly lower than that of young adults with normal hearing $\left({ }^{*} p<0.05\right)$.

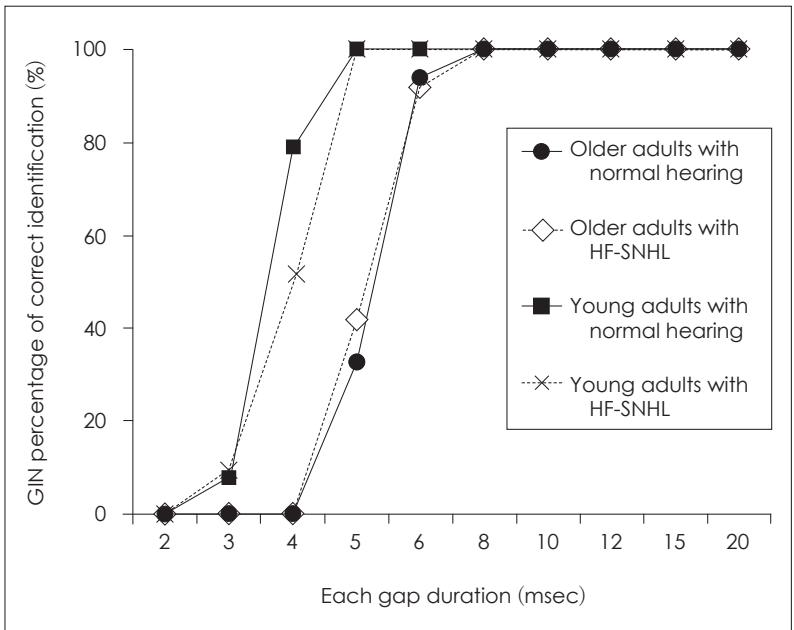

Fig. 5. Psychometric functions for each gap duration for both older and young adults with normal hearing or with high frequency sensorineural hearing loss (HF-SNHL). There was no significant difference of overall psychometric curve between subjects with normal hearing and HF-SNHL except lower Gaps-In-Noise (GIN) percentages of correct identification of $4 \mathrm{msec}$ in young adults with HF-SNHL than in young adults with normal hearing.

Table 2. Summary of the results of multiple regression analyses of the GIN threshold for various factors in older adults

\begin{tabular}{lccc}
\hline & $R^{2}$ & $\begin{array}{c}\text { Standardized } \\
\beta \text { coefficient }\end{array}$ & p-value \\
\hline Age & 0.285 & 0.383 & 0.027 \\
Sex & & 0.328 & 0.409 \\
Presence of HF-SNHL & 0.034 & 0.933 \\
Threshold at 4 kHz & 0.069 & 0.802 \\
Threshold at 8 kHz & -0.324 & 0.528 \\
Pure-tone average & -0.097 & 0.679 \\
Speech reception threshold & 0.223 & 0.332 \\
Speech discrimination score & -0.120 & 0.509 \\
\hline
\end{tabular}

HF-SNHL: high frequency sensorineural hearing loss, GIN: GapsIn-Noise
서 정상 청력군 33\%, 고음역 난청군 42\%였으며, $6 \mathrm{msec}$ 에서 정 상군 94\%, 고음역 난청군 92\%로 두 군 간에 유의한 차이를 보 이지 않았다. $8 \mathrm{msec}$ 이상의 간격에서는 모두 $100 \%$ 였다. 한 편, 젊은 성인에서는 $4 \mathrm{msec}$ 에서 정상군 $79 \%$, 고음역 난청군 에서 $52 \%$ 로 두 군 간에 유의한 차이가 있었고, $5 \mathrm{msec}$ 이상의 간격에서는 모두 $100 \%$ 로 노인에서의 심리측정 함수와는 다른 양상을 보였다. GIN 역치와 여러 임상적 요인들의 관계를 분 석한 결과, 노인에서 나이가 유일한 상관성을 보였다(Table 2). 성별, 고음역 감각신경성 난청의 유무, $4 \mathrm{kHz}$ 및 $8 \mathrm{kHz}$ 에서의 청력역치, 순음청력평균, 어음청취역치, 어음명료도는 GIN 수 행력과 관련성이 없었다.

\section{고 찰}

시간은 주파수, 크기와 함께 소리를 구성하는 요소로서 어 음, 문장 및 음악에서 시간에 따른 소리의 변화는 매우 중요한 정보를 전달하게 된다.14) 우리의 청각계가 가지고 있는 시간적 해상도는 나이의 증가에 따라 감소하는 것으로 알려져 있는 데, ${ }^{3,415-17)}$ 본 연구에서도 GIN 검사상 젊은 성인에서보다 노인 에서의 역치가 높고, 정답 백분율이 낮은 것으로 조사되었다. 하지만, 젊은 성인에서는 고음역 난청군이 정상 청력군에 비해 낮은 GIN 수행력을 보인 반면, 노인에서는 고음역 난청 유무 에 따라 GIN 결과의 차이를 보이지 않았다. 이는 젊은 성인에 서는 간격 탐지와 연관된 시간적 해상도에 고음역의 신호 청 취력이 상당한 영향을 미치지만, 노인에서는 $4 \mathrm{kHz}$ 이상의 주 파수에서 고음역 감각신경성 난청이 기여하는 바가 크지 않음 을 의미한다. 이는 이명과 관련된 고음역 난청 또는 순음청력 검사상 역치가 간격 탐지 능력과 관련이 없다는 기존의 보고 들과 일치되는 소견이다. ${ }^{17,18)}$ 나이와 정상 순음청력평균을 최 대한 엄격하게 맞추기 위해 노인군은 65 70세, 젊은 성인군은 20 29세로 제한하였으나, 그럼에도 불구하고 순음청력평균이 젊은 성인군(6.5 $\pm 3.6 \mathrm{~dB})$ 에 비해 노인군(14.8 $\pm 3.8 \mathrm{~dB})$ 에서 약 간 높게 나타난 점은 교란 변수로서 고려되어야 한다. John 등기 은 감각신경성 난청의 유무가 GIN 역치를 결정하는 가장 강 력한 요인이면서도 나이 또한 독립된 인자라고 보고하였고, Harris 등 ${ }^{19}$ 은 간격 탐지에 대한 대뇌의 사건-관련 전기반응 (event-related potentials) 분석을 통해 젊은 성인보다 노인들 이 간격을 잘 탐지하지 못하는 것이 주의력(attention)과 대뇌 처리 속도(cortical processing speed)의 감소와 밀접한 관계 가 있다고 보고하였다. 젊은 성인에서는 소리 자극의 시간적 인지 과정에서 고음역의 청력 감소만으로도 간격 탐지 능력이 저하될 수 있으나, 중추 청각계의 기능에 나이와 관련된 변화 가 생긴 이후에는 고음역의 소리 정보 이외의 다른 요인들이 
시간적 해상도에 더 중요하게 관여할 것으로 보인다. 노인 대상자 들에게 인지 기능 검사 같은 뇌기능 검사를 시행하여 간격 탐지 결과에 영향을 미치는 다른 요인을 확인할 수도 있을 것이다.

청각의 시간적 해상도를 확인하는 GIN 검사와 일반적인 간 격 탐지 검사(gap detection test) 사이에는 방법이나 결과상 의 차이점이 있다. 우선 GIN 검사는 사람이 들을 수 있는 20 $\mathrm{Hz} 20 \mathrm{kHz}$ 의 모든 주파수를 동일한 양으로 포함하는 백색 잡음을 사용한다. ${ }^{6}$ 협대역 잡음이나 광대역 잡음 등 다양한 자극들을 사용하는 간격 탐지 검사는 주로 연구 목적으로 사 용되었고, 임상적으로는 널리 적용되지 못하였다. 임상적으로 간격 탐지 검사가 활성화되지 못한 이유는 시간이 많이 소모되 어 다른 청각학적 검사들과 함께 사용하기가 어렵고, 특히 긴 검사 시간을 견디지 못하는 노인이나 소아를 대상으로 할 때 검사 결과의 신뢰도가 낮아서 현실적으로 적합하지 않기 때문 이다.6,16,20) 본 연구는 GIN 검사가 젊은 성인에서뿐만 아니라 노인에서도 임상적으로 간격 탐지 능력을 평가하는 데 유용한 도구라는 이전의 보고들과 동일한 연장선상에 있다.,1,13) 소음 의 간격은 시간상에서뿐만 아니라 소리의 강도 영역(intensity domain)에서도 일시적인 소리의 부재를 의미하기 때문에 청 각의 시간적 해상도와 음량의 인지는 둘 다 GIN 수행력과 관 련이 있을 수 있다. 이러한 약점를 보완하기 위해 시간 영역에 서 소리의 강도를 0 으로 하지 않고 백색 잡음을 사인양 진폭 변조(sinusoidal amplitude modulation)를 시행하여 약한 강 도로 채워주는 시간적 변조 변환 함수(temporal modulation transfer function)가 이용되기도 한다. 간격 탐지 역치에 근거 한 시간적 해상도와 시간적 변조 변환 함수 측정값 간에 일관 된 상관 관계를 보이고 있어 ${ }^{21)}$ 여전히 GIN 검사는 청각의 시 간적 처리 능력을 평가하는 데 중요한 방법 중 하나이다.

무음 구간을 식별하는 평균 $\mathrm{GIN}$ 역치와 정답 백분율은 18 명의 정상 청력 노인군에서 각각 $6.0 \pm 0.8 \mathrm{msec}$ 와 $60.6 \pm 3.9 \%$ 로 나타났고, 정상 청력인 젊은 성인에서는 $4.2 \pm 0.5 \mathrm{msec}$ 와 $76.9 \pm 4.3 \%$ 로 측정되었다. 정상 대상자에 대한 문헌 고찰에서 평균 $\mathrm{GIN}$ 역치는 4.2 5.7 msec이고 평균 정답률은 69 78\% 로 조사되었다. ${ }^{6-9,20)}$ 본 연구에서의 젊은 성인군 24 명에서 얻 은 값은 기존의 결과들 중 특히 Musiek 등과 과 Shin 등 $^{8}$ 의 수치와 비슷하다. 보편적인 정상 범위로 평균 \pm 2 표준편차가 이용되는 점을 고려했을 때 본 연구의 정상 청력인 젊은 성인 군에서 계산되는 $\mathrm{GIN}$ 수행력의 정상 한계는 $5.2 \mathrm{msec}$ 이하, 68.3\% 이상이다. 이는 20대 청년 연령층에서 평균값을 구하고 정상 범위를 확인한 것이므로 노인, 소아, 중장년층 등 나이가 다른 대상자들의 GIN 검사 자료를 해석하는 데 참고할 수 있 다. 정상 청력인 젊은 성인군의 GIN 수행력은 모두(100\%) 정 상 범위 내에 있었고, 고음역 난청이 있는 젊은 성인 21명 중
GIN 역치는 19명(90.5\%)이 정상, 정답률은 18 명(85.7\%)이 정상 이었다. 한편, 정상 청력인 노인 18명 중 GIN 역치는 4명(22.2\%), 정답률 1명(5.6\%)이 정상 범위 내에 있었고, 고음역 난청이 있 는 노인 24명 중 $\mathrm{GIN}$ 역치는 10명(41.7\%), 정답률은 3명(12.5\%) 이 정상이었다. 이러한 분포를 보인 점도 나이가 청각의 시간 적 해상도에 영향을 미치는 반면 노인에서 고음역 난청의 유 무는 관련이 없다는 것을 뒷받침한다. 하지만, 대상자 모집에 한계가 있어 나이를 연속 변수로 설정하지 못하고 노인군과 젊은 성인군으로 나누어 비교 분석한 점은 임상적으로나 통계 적으로나 본 연구의 약점으로 판단된다.

고음역 감각신경성 난청의 주파수 범위나 심한 정도에 따른 시간적 해상도의 변화를 확인하는 것도 GIN 검사와 관련된 중요한 주제 중 하나이다. Feng 등 ${ }^{4}$ 은 22 68세의 환자 50명 을 정상 청력군, $2 \mathrm{kHz}$ 부터 고음역 난청이 시작되는 군, 3 $\mathrm{kHz}$ 부터 고음역 난청이 시작되는 군, $4 \mathrm{kHz}$ 부터 고음역 난청 이 시작되는 군으로 나누어 간격 탐지 역치와 시간적 변조 변 환 함수(temporal modulation transfer function)를 검사하여 정상군과 고음역 난청군 간에 유의한 차이가 있고, 특히 2 $\mathrm{kHz}$ 부터 고음역 난청이 시작되는 군의 시간적 해상도가 가장 떨어졌다고 보고하였다. 여기에서는 각 고음역 난청군 간에 나 이가 다양한 환자들이 섞여 있는 단점을 극복하기 위해 나이 가 대등한(age-matched) 정상 대조군을 설정하였다. 본 저자 들은 이번 연구에서 $3 \mathrm{kHz}$ 까지는 정상이고 $4 \mathrm{kHz}$ 이상의 주 파수에서 청력 감소가 시작되는 환자들만을 대상으로 하였 고, $2 \mathrm{kHz}$ 또는 $3 \mathrm{kHz}$ 에서 고음역 난청이 존재하는 노인에서 의 GIN 수행력를 검사하여 연령과 고음역 난청의 주파수 범 위에 따른 시간적 해상도를 분석하는 후속 연구를 진행 중에 있다. 또한, 본 연구에서의 고음역 난청은 주로 경도-중등도 (mild-to-moderate)의 청력 저하이기 때문에 고도-심도(severeto-profound) 난청이 있는 노인에서의 GIN 검사에 대한 연구 가 추가적으로 시행되어야 할 것이다.

노인에서 다중 회귀분석 결과를 나타낸 Table 2에서 고음역 난청의 유무, $4 \mathrm{kHz}$ 나 $8 \mathrm{kHz}$ 에서의 역치값은 $\mathrm{GIN}$ 역치와 관 련성이 없었고, 나이만이 GIN 역치와 유의한 상관 관계가 있 었다. $\mathrm{R}^{2}$ 값이 0.285 인 것은 통계적으로 $\mathrm{GIN}$ 역치의 변동이 나 이의 변동에 의해 $28.5 \%$ 설명되고 나머지는 이 모형으로 설명 되지 않는다는 것을 의미한다. 이 결과 또한 순음역치 평균이 정상인 노인군에서 고음역 난청 자체는 GIN 수행력에 영향을 미치지 못하고, 나이의 증가가 GIN 검사 결과를 악화시키는 요인이 되는 점을 지지한다.

\section{REFERENCES}

1) John AB, Hall JW 3rd, Kreisman BM. Effects of advancing age 
and hearing loss on gaps-in-noise test performance. Am J Audiol 2012;21(2):242-50.

2) Plack CJ, Viemeister NF. Suppression and the dynamic range of hearing. J Acoust Soc Am 1993;93(2):976-82.

3) Zwicker E, Schorn K. Temporal resolution in hard-of-hearing patients. Audiology 1982;21(6):474-92.

4) Feng Y, Yin S, Kiefte M, Wang J. Temporal resolution in regions of normal hearing and speech perception in noise for adults with sloping high-frequency hearing loss. Ear Hear 2010;31(1):115-25.

5) Won JH, Drennan WR, Nie K, Jameyson EM, Rubinstein JT. Acoustic temporal modulation detection and speech perception in cochlear implant listeners. J Acoust Soc Am 2011;130(1):376-88.

6) Musiek FE, Shinn JB, Jirsa R, Bamiou DE, Baran JA, Zaida E. GIN (Gaps-In-Noise) test performance in subjects with confirmed central auditory nervous system involvement. Ear Hear 2005;26 (6):608-18.

7) Samelli AG, Schochat E. The gaps-in-noise test: gap detection thresholds in normal-hearing young adults. Int J Audiol 2008;47 (5):238-45.

8) Shinn JB, Chermak GD, Musiek FE. GIN (Gaps-In-Noise) performance in the pediatric population. J Am Acad Audiol 2009;20 (4):229-38.

9) Sanches SG, Sanchez TG, Carvallo RM. Influence of cochlear function on auditory temporal resolution in tinnitus patients. Audiol Neurootol 2010;15(5):273-81.

10) Glasberg BR, Moore BC, Bacon SP. Gap detection and masking in hearing-impaired and normal-hearing subjects. J Acoust Soc Am 1987;81(5):1546-56.

11) Dubno JR, Dirks DD. Associations among frequency and temporal resolution and consonant recognition for hearing-impaired listeners. Acta Otolaryngol Suppl 1990;469:23-9.

12) Snell KB. Age-related changes in temporal gap detection. J Acoust Soc Am 1997;101(4):2214-20.

13) Vaidyanath R, Yathiraj A. Comparison of performance of older adults on two tests of temporal resolution. Am J Audiol $2015 \mathrm{Feb} 3$ [Epub]. http://dx.doi.org/10.1044/2015_AJA-14-0064.

14) Park MH. Temporal processing in the auditory system. Korean $J$ Otorhinolaryngol-Head Neck Surg 2011;54(9):585-91.

15) Hall JW, Buss E, Grose JH, Roush PA. Effects of age and hearing impairment on the ability to benefit from temporal and spectral modulation. Ear Hear 2012;33(3):340-8.

16) An YH, Jin SY, Yoon SW, Shim HJ. The effects of unilateral tinnitus on auditory temporal resolution: gaps-in-noise performance. Korean J Audiol 2014;18(3):119-25.

17) Snell KB, Frisina DR. Relationships among age-related differences in gap detection and word recognition. J Acoust Soc Am 2000;107 (3):1615-26.

18) Boyen K, Başkent D, van Dijk P. The Gap Detection Test: Can It Be Used to Diagnose Tinnitus? Ear Hear 2015;36(4):e138-45.

19) Harris KC, Wilson S, Eckert MA, Dubno JR. Human evoked cortical activity to silent gaps in noise: effects of age, attention, and cortical processing speed. Ear Hear 2012;33(3):330-9.

20) Zaidan E, Baran JA. Gaps-in-noise (GINC) test results in children with and without reading disabilities and phonological processing deficits. Int J Audiol 2013;52(2):113-23.

21) Eddins DA. Amplitude modulation detection of narrow-band noise: Effects of absolute bandwidth and frequency region. J Acoust Soc Am 1993;93(1):470-9. 